\title{
Analysis of Black Market in Central African Republic's Mining Sector: A Multiple-Regression Analysis
}

\author{
Befio Paulin Epaphrodite, Ph. D. in Applied Economics
}

\author{
Assistant Professor, University of Bangui (Central African Republic), Faculty of Economics and Management, Central African \\ Republic \\ befio 82@yahoo.fr
}

\begin{abstract}
In this work, we emphasize on the analysis of the effect of the black market in the Mining sector in the Central African Republic's economy (GDP), using the relationship between mining quantity exported and the price divided into legal and illegal price. The data collected were analyzed and tested using Ordinary Least Square (OLS). The result of this work shown that legal price coefficient indicated for each increase of 1 percent in the legal Price, holding illegal price constant, the expected change in Product is predicted to be about 52\%, this mean change in the legal price has a positive effecton the official production and statistically significant ( $t$-value is 2.745165).However, change in illegal price has a negative effect on production (about 53\% with t-value equal to 2.792635 of statistical significance). Regarding this work, in order to make mining sector more efficient, the Central African Republic's government should try to develop other sectors such as agriculture and manufacture for diversifying sources of state revenue purpose. It should also increase the export earnings of the country throughout income from mining by strengthening the country's integration into the global economy but also by ensuring the socio-economic development of mining workers.
\end{abstract}

Keywords-Mining, Black market, legal price, Illegal price, Economy.

\section{INTRODUCTION}

According to recent research on prospection of the Mining Department of the Ministry of Mines and Hydrology, the Central African Republic's subsoil has several kinds of mineral resources like 470 mineral indexes, grouped into 33 species. Among the most important, are Bakouma uranium deposit (20,000 tons of Uranium metal, iron ore deposit Bogoin (3.5 million tons of ore grading 60 - 65\% iron) and limestone deposits of Fatima and Bobassa(10 million tons of ore with an average of $92 \%$ carbonates). Among these mineral resources, only the diamond and gold resources are used today in the traditional way. Diamonds and gold mining are almost present over the whole territory of Central African Republic for the reason that the country is endowed with these mineral resources. But its production, which is exported in the rough, does not contribute as much as possible to the economy of the country: diamond and gold mining is part of the whole industry which contributes only 15\% to the GDP (Bank, 2010). The production is weakened by a bad quality of governance characterized by the corruption in this sector. Also, the traditional way of mining does not help this sector to be sufficiently efficient in order to contribute well to the Central African Republic's economy.

However, mining (gold and diamond) is among important resources of the Central African Republic (CAR) in terms of export earnings: official production, mostly traditional, alluvial diamond of very good quality (diamond jewelry) is produced approximately 500000 carats a year. Real output is estimated at about double, which means there is a significant economy of smuggling in this sector. This signals the presence of a high level of an illegal (black) market in the CAR's mining sector. Production, trade and diamond cutting, are activities that are regularly planned to be nationalized, rather than liberalized. Thus, the question we can ask is what is the effect of the black market in mining sector on the CAR's GDP? In other words, how does the presence of smugglers in the CAR's mining market affect its economy? Therefore, in this work, we emphasize on the analysis of the effect of the black market in the Mining sector in the Central African Republic's economy (GDP), using econometrics tools.

The question of sovereignty over natural resources has preoccupied the minds for decades. Mirabeau already has said before the French Constituent Assembly in 1789 that the nation has the right to dispose of natural resources of its 
territory. Political sovereignty exercised in a given territory takes sovereignty over natural resources of this territory. More recently, the UN has addressed the issue in the early years of its creation. She was raised for the first time in 1952, during the work of the Committee on Human Rights. It is against the proposal by Chile that the commission decided to include in the draft covenants which would lead to the adoption of a Universal Declaration of Human Rights, a provision that "the right of peoples to self-determination also includes a right to permanent sovereignty over their natural wealth and resources".

The failure or the wickedness of the enforcement of the property right causes the natural resources to become resource curse which is defined as a paradoxical situation in which countries with a natural (mineral) resources endowment face stagnant growth or even more economic contraction. The resource curse occurs occur as a country begins to delight all of its energies on a single industry, such as mining, and put less effort on other major sectors. This imperfection in the arrangement of worldwide business permits strongmen and common warriors to catch for them the money that purchasers around the globe spend on regular products. The strongmen and common warriors have no privilege to this money. The gift of natural resources transforms into a revile when dictators and extremists are free to commercialize a nation's resources without the assent of the general population, and to utilize the returns in manners that exacerbate the general population off. These reason leads the resources to be exchanged in illicit way which we call "black market" in terms of our analysis.

\section{LITERATURE REVIEW}

The mining market in CAR is highly such a sensitive topic because of the complete implication of the Govern ment, this last consider the mining sector as the main source of revenue and also the means to strengthen its power. This leads to a high level of corruption in the sector. According to many studies inefficiencies associated with government interventions in many developing and even developedcountries are well known on misallocation of resources (Lal, 1985); on corruption (Minogue \& Cariño, 2006) and (KEREKES \& WILLIAMSON, 2008). In this work before we try to analyze the effect of black market in the mining sector on CAR's economy, we have examined what causes illegality in the mining market and we found one of these causes even the main one is the high level of corruption (Wendschlag, 2009) in this market. Beside corruption, generating a lack of institutional trust (Beckert \& Wehinger, 2011), illegality is caused by a high taxation system; there are other limits such as the low education level of miners, lack of equip ment for mining department to control mining zones, fragility of the CAR's borders that allow foreigners smugglers to freely circulate in the countryside, especially in mining zones, the presence of different armed group (rebels) etc. All these push mining resource to be commercialized in an illegal way due to the failure of the property right.

A right of ownership (Property Right) means any physical or immaterial entity that belongs to a person or jointly to a group of persons or to a legal entity such as a corporation. (Ostrom \& Hess, 2011). Regarding the nature of the property, an owner has the privilege of consuming, selling, renting, mortgaging, transferring, exchanging or destroying it, or denying others to do so(Wenar, 2008). Out of the main types of property that are widely recognized, the most important is real estate (the combination of land and its potential improvements).

Talking about property right, there are two distinct meanings: economic property rights (Besley \& Ghatak, 2010) and legal property rights (Meinzen-Dick \& Pradhan, 2002). The economic property rights of an individual over a commodity or an asset are the individual's capacity, in terms of anticipation, to consume the good or the services of the asset directly or to consume it indirectly through trade. These can include the right to use an as set, the right to earn income from an asset and contract over the terms with other individuals, and the right to transfer ownership rights permanently to another party. The legal property rights are those that are recognized and enforced by the government.

In the case of our analysis the real property right is highlighted. In the other hands the natural resources' right is characterized by the right of using a piece of land defined by boundaries to which ownership is usually ascribed, including any improvements on this land. In the case of our analysis, the land can be represented by the mines. As we see in previous chapter, in CAR mines are owned by the state (Government). Property right is one of the principal characteristics of Institutional Economics.

Institutional economics pay more attention on understanding the role of that play evolutionary process and institutions in shaping economic behavior. Its original attention lay in Torstein Veblen's instinct-oriented dichotomy between technology and the "ceremonial" sphere of society. Its name and milestone elements trace back to a 1919 American Economic Review article by Walton $\mathrm{H}$. Hamilton (Hodgson, 2005). Institutional economics is a branch of economics that stresses a larger study of institutions and perceives markets as the result of the complex interconnexion of these different institutions (individuals, firms, states, social norms). The first tradition 
of this branch continues today to be a dominant heterodox approach to the economy. An important variant is the new institutional economy (NIE) of the late 20th century, which incorporates the subsequent developments of neoclassical economics into analysis.

NIE has its roots in two articles by Ronald Coase ${ }^{1}$, "The Nature of the Firm" (1937) and "The Problem of Social Cost" (1960). In the latter case, Coase's theorem (so-called later) argues that, without transaction costs, other property rights assignments can equivalently internalize conflicts and externalities. Therefore, a comparative institutional analysis arising from such missions is needed to make recommendations on effective internalization of externalities and institutional design, including in law and economics(Klein, 2008).

\section{MATERIALS AND METHOD}

Researchers attested that it is hard to measure activities in an illegal economy (shadow economy) since the idea of commercialization in this economy is to hide from a possible detection. Therefore, researchers have to employ indirect methods to deal with the problem. These methods include surveys of citizens, discrepancies in national income accounting, money demand estimation and electricity use(Gomis-Porqueras, Peralta-Alva, \& Waller, 2011).

However, in achieving this work, we drown some statistical data from Mining Department and Institutions of Central African Republic. Also, documentation such as mining law and personalities' speeches has been consulted to help in this analysis. The data collected (secondary data) were analyzed and tested using Ordinary Least Square (OLS). These data are time-series collected monthly from 2007 to earlier (first trimester) 2011.

The model used is based on the market mechanism which is one of fundamental principles of Microeconomics (Bénassy, 2011). The market mechanis $m$ is an economical principle in a free market for price to change in order to reach the market clearing (in equilibrium) ${ }^{2}$. In this situation there is not excess of demand and supply, there is no pressure of subsequent change in price. When some heterogeneous factors such as illegality come to change the free market

${ }^{1}$ Ronald Harry Coase, born December 29th 1910 is a British-born, American-based economist and the Clifton R. Musser Professor Emeritus of Economics at the University of Chicago Law School. After studying with the University of London External Program in 1927-29, Coase entered the London School of Economics, where he took courses with Arnold Plant.He received the Nobel Memorial Prize in Economics in 1991.

2Market situation in which demand equalsto supply conditions, the market might not be clear. Then it is important to analyze these factors.

To do so, for reasons that we already explained, we are going to use the supply function. The supply function is thus a positive relationship between the quantity supplied and the price:

$\mathrm{Qs}=\mathrm{Qs}(\mathrm{P})^{3}$. This relationship indicates the quantity of a product that producers are willing to sell at a given price, keeping all other factors that may affect quantity supply constant. This means that the quantity provided may depend on variables other than price. In the other hands, the quantity that produced does not depend only on the price the producers receive when they sell their products, but also on their cost of production, including wages, interest charges and the cost of raw materials. In our model, all these other factors are included in the error term. The theoretical model can be written as following:

$\boldsymbol{Q}=\boldsymbol{a}+\boldsymbol{b P}$

We divide $\mathrm{P}$ into legal and illegal price in order to analyze the illegal effect. Using econometric functional form, we get:

$\boldsymbol{Q}_{\boldsymbol{t}}=\boldsymbol{\beta}_{\mathbf{0}}+\boldsymbol{\beta}_{1} * \boldsymbol{L} \boldsymbol{P}_{\boldsymbol{t}}+\boldsymbol{\beta}_{\mathbf{2}} \boldsymbol{I} \boldsymbol{P}_{\boldsymbol{t}}+\boldsymbol{\mu}_{\boldsymbol{t}}(2)$

Where, $\mathbf{Q}$ (dependent variable) represents the supply (total export) of the mining product; LP (independent variables) is the legal price (legal market price) and IP, the illegal price (illegal market price) which affect the total production. $\boldsymbol{\mu}_{\mathrm{t}}$ is defined as a random disturbance which may take either a positive or a negative value. $\boldsymbol{\beta}_{\mathbf{0}}$ is the intercept of our equation, it is also called the constant term. Economically, it can be defined as the autonomous production. $\boldsymbol{\beta}_{\mathbf{1}}$ and $\boldsymbol{\beta}_{\mathbf{2}}$ are ceteris paribus, parameter that we are going to estimate. They measure the effect of a change in the dependent variable $(\mathbf{Q})$ in response to a change (1-unit) in the independent variables $(\mathrm{P})$.

By taking log of both sides of the equation, we get:

$\log Q_{t}=\beta_{0}+\beta_{1} * \log L P_{t}+\beta_{2} \log I P_{t}+\mu_{t}$ (3)

The log form allows us to analyze the percentage change in dependent variable in response to the percentage change in the explanatory variables using ceteris paribus (Becker et al., 2011).
${ }^{3} \mathrm{Qs}=\mathrm{a}+\mathrm{bP}$, the price and the quantity change in the same direction. 
IV. DATA ANALYSIS AND RESULTS

Table.1: Stationary test result (ADF)

\begin{tabular}{|c|c|c|c|c|c|c|}
\hline & \multicolumn{3}{|c|}{ Level } & \multicolumn{3}{|c|}{ First difference } \\
\hline Variables & $\begin{array}{c}\text { ADF } \\
\text { C\&T }\end{array}$ & $\begin{array}{c}\text { Critical } \\
\text { Value (5\%) }\end{array}$ & Result & $\begin{array}{c}\text { ADF } \\
\text { C\&T }\end{array}$ & $\begin{array}{c}\text { Critical } \\
\text { Value (5\%) }\end{array}$ & Result \\
\hline Q & $\begin{array}{c}-4.44146 \\
(0.0010)\end{array}$ & -2.941145 & I (0) & $\begin{array}{c}-7.415354 \\
(0.0000)\end{array}$ & -2.945842 & I (0) \\
\hline LP & $\begin{array}{c}-1.359316 \\
(0.5914)\end{array}$ & -2.943427 & I (1) & $\begin{array}{c}-13.71946 \\
(0.0000)\end{array}$ & -2.943427 & I (0) \\
\hline IP & $\begin{array}{c}-1.354404 \\
(0.5937)\end{array}$ & -2943427 & I (1) & $\begin{array}{c}-13.71705 \\
(0.0000)\end{array}$ & -2.943427 & I (0) \\
\hline
\end{tabular}

Source: Author computation

Figures in bracket denote MacKinnon (1996) one-sided p-values.

All the variables are stationary at first difference except $Q$ which is also stationary in level but the result is more relevant in firs difference.

Table.2: Multiple-Regression result

Dependent variable: LQ

\begin{tabular}{|c|c|c|c|}
\hline Variables & Coefficients & t-values & Probability \\
\hline C & 20.58057 & 7.910494 & 0.0000 \\
LLP & 52.21851 & 2.745165 & 0.0097 \\
LIP & -53.14617 & 2.792635 & 0.0005 \\
AR (2) & 0.550057 & 3.825955 & 0.0005 \\
\hline \multicolumn{2}{|c|}{$\mathrm{R}^{2}=0.461270$} & Adj. $\mathrm{R}^{2}=0.412294$ & F-statistic= 9.418385 $\quad$ p-value $=0.000121$ \\
\hline
\end{tabular}

Source: Author computation

Where, LLP, LIPand LQ arerespectively the natural logarithm values of legal price, illegal price and the exported values of mining products.

\section{DISCUSSION}

First, in the estimation result, the intercept of the mining product (export) is 20.58056997 about $21 \%$ changes and statistically significant with t-value of 7.910494 . That is mean when the rate of change in Prices (legal and illegal) is zero the expected change in the mining product is about $21 \%$, meaning that mining product is expected to increase by this percentage on average during a year in which the change in prices is zero. This change can be explained by the expected producers' behavior, because they expect the prices to increase in the next year. The legal price coefficient also indicated that for each increase of 1 percent in the legal Price, holding illegal price constant, the expected change in Product is predicted to be about 52\%, this mean change in the legal price has a positive effecton the official production and statistically significant (t-value is 2745165).While change in illegal price has a negative effect on production (about 53\% with t-value equal to 2.792635 of statistical significance). This can be seen by the negative sign of its coefficient (-53.14617). This can be explained by the fact that illegal buyers fix a price higher than the legal one in order to attract producers and when this price rises, people prefer to sell their product in the black market to avoid the confiscation of their product. Recall that the number of buyers in the illegal market is larger than those who prefer to buy in the legal way, because of the presence of "debrouillards" supported by some of miners who cannot pay their license or don't trust official mining department in the way it treats them.

The adj. $\mathrm{R}^{2} 0.4612$ shows 46 percent of variation in dependent variable is explained by independent variables. The joint significant given by F-stat 9.4183 p-value (0.00) shows that independent variables are significant determinant of dependent variable.

The variable $\mathbf{A R}(\mathbf{2})$ which stands for the auto-regressive process was included in the equation to deal with the serial correlation in the model. This process is rendered explicit by the following equation:

$\boldsymbol{u}_{\boldsymbol{t}}=\mathbf{0 . 5 5 0 0 5 7} * \boldsymbol{u}_{t-2}+\boldsymbol{\varepsilon}_{\boldsymbol{t}}$ (with $\boldsymbol{\varepsilon}_{\boldsymbol{t}}$ individual identical distributed) 
This equation fulfils the stable condition for the process to be weekly dependent with the absolute value of the parameter errors lag less than one $(|0.55|<1)$.

\section{CONCLUSION}

The paper examines the effect or impact of illegal mining on the economic growth of CAR, the data covers the period of 3 years (1972-2011) monthly collected; unit root test and OLS method was used. The result of unit test shows the variables are stationary in first difference.

The result of this work shows that illegal market in mining sector has a negative effect on the economy of CAR. When illegal price increases mining workers prefer to sell their product to smugglers because they don't trust legal department. In illegal markets, most legal institutions taking part in protecting property rights are beyond expectation for the actors concerned, while social relations suffer from a lack of institutional trust. As drawback, it will cause a lost to the Government in terms of revenue. Indeed, the CAR's Government gets the big part of its revenue from mining sector.

In order to make mining sector more efficient, the CAR's government should try to develop other sectors such as agriculture and manufacture by diversifying sources of state revenue through the promotion of mineral resource. It should also increase the export earnings of the country throughout income from mining by strengthening the country's integration into the global economy but also by ensuring the socio-economic development of mining workers.

Economic development is a conquest which involves the promotion of entrepreneurship and enterprise, Government should liberalize the sector to involve private sector. To this end, it should take responsibility to bring together necessary conditions for:

- preparation of geological infrastructure;

- the creation of an enabling environment for private investment;

- sector promotion;

- the capacity building of structures in charge of supervision and control of the actors in the mining sector;

- Increase of involvement of private sector in exploration, development and exploitation of mineral resources of the country.

Above all these measures safe governance still remains the necessary condition for the improvement of the sector. CAR's government should strengthen the capacity of EITI
(Extractive Industries Transparency Initiative $)^{4}$ in order to reduce corruption.

\section{REFERENCES}

[1] Bank, T. H. E. W. (2010). The World Bank Group in Extractive Industries 2010. Public Law. https://doi.org/10.1126/science.310.5754.1607

[2] Becker, G. S., Murphy, K. M., Grossman, M., Wenar, L., Dietrich, B. C., Bank, T. H. E. W., ... Africa, S. (2011). [Textbook]Introductory Econometrics. Ssrn, 7(2), 111-208. https://doi.org/10.1561/0700000042

[3] Beckert, J., \& Wehinger, F. (2011). In the Shadow Illegal Markets and Economic Sociology Jens Beckert and Frank Wehinger. Illegal Markets and Economic Sociology, 11(2012), 1-26. https://doi.org/10.1093/ser/mws020

[4] Bénassy, J. P. (2011). Macroeconomic Theory. Macroeconomic

Theory. https ://doi.org/10.1093/acprof:osobl/9780195387711.0 01.0001

[5] Besley, T., \& Ghatak, M. (2010). Property rights and economic development. Handbook of Development Economics. https://doi.org/10.1016/B978-0-44452944-2.00006-9

[6] Go mis-Porqueras, P., Peralta-Alva, A., \& Waller, C. J. (2011). Quantifying the Shadow Economy: Measurement with Theory. Ssrn. https://doi.org/10.2139/ssrn.1856254

[7] Hodgson, G. M. (2005). 'Institution' by Walton H. Hamilton. Journal of Institutional Economics. https://doi.org/10.1017/S1744137405210202

[8] KEREKES, C. B., \& WILLIAMSON, C. R. (2008). Unveiling de Soto's mystery: property rights, capital formation, and development. Journal of Institutional Economics.

https://doi.org/10.1017/S1744137408001100

[9] Klein, P. G. (2008). Opportunity discovery, entrepreneurial action, and economic organization. Strategic Entrepreneurship Journal. https://doi.org/10.1002/sej.50

[10] Lal, D. (1985). Nationalis m, socialis $m$ and planning: Influential ideas in the South. World Development. https://doi.org/10.1016/0305-750X(85)90120-2

[11] Meinzen-Dick, R., \& Pradhan, R. (2002). Legal

4The Central African Republic was recognized as Candidate on November 21, 2008 and became the 24th country implementing the EITI. She had until November 20, 2010 to complete its validation. It submitted its final validation report to the Board in November 18, 2010. The Central African Republic was recognized by the Board of EITI as EITI Compliant in March 1, 2011 
Pluralism and Dynamic Property Rights. Food Policy. https://doi.org/10.1016/j.agsy.2004.07.005

[12] Minogue, M., \& Cariño, L. V. (2006). Introduction: Regulatory governance in developing countries. In Regulatory governance in developing countries. https://doi.org/10.1017/CBO9781107415324.004

[13] Ostrom, E., \& Hess, C. (2011). Private and Common Property Rights. SSRN. https://doi.org/10.2139/ssrn.1936062

[14] Wenar, L. (2008). International Property Rights and the Resource Curse. Philosophy and Public Affairs, 36(1), 2-32.

[15] Wendschlag, M. (2009). Handbook of New Institutional Economics. Scandinavian Economic History Review. https://doi.org/10.1080/03585520903122574 